\title{
Limited variation in mitochondrial DNA of maize-associated Ostrinia nubilalis (Lepidoptera: Crambidae) in Russia, Turkey and Slovenia
}

\author{
SugihiKo HOSHIZAKI ${ }^{1}$, RYôta WASHIMORI ${ }^{1}$, ShUn-ICHI KUBOTA ${ }^{1 *}$, ANDREI N. FROLOV ${ }^{2}$, Daisuke \\ KAGEYAMA $^{1 * *}$, Stanislav GOMBOC $^{3}$, Suguru OHNO ${ }^{1 * * *}$, Sadahiro TATSUKI $^{1}$ and Yukio ISHIKAWA ${ }^{1}$ \\ ${ }^{1}$ Laboratory of Applied Entomology, Graduate School of Agricultural and Life Sciences, The University of Tokyo, Bunkyo-ku, \\ Tokyo 113-8657, Japan; e-mail: ahossy@mail.ecc.u-tokyo.ac.jp \\ ${ }^{2}$ Laboratory for Phytosanitary Diagnostics and Forecasts, All-Russian Institute for Plant Protection, St. Petersburg 196600, Russia \\ ${ }^{3}$ Phytosanitary Administration of the Republic of Slovenia, Einspielerjeva 6, SI-1000 Ljubljana, Slovenia
}

Key words. Ostrinia, mtDNA, COII, geographical variation, phylogeography

\begin{abstract}
A sequence analysis of the mitochondrial cytochrome oxidase subunit II (COII) gene in Russian and Turkish maizeassociated populations of Ostrinia nubilalis and a Slovenian population of $O$. nubilalis probably infesting maize revealed little diversity. This lack of diversity may have resulted from bottleneck event(s) when the maize-associated population of $O$. nubilalis expanded from small population(s) in association with the cultivation of maize in Europe ca. 500 years ago. In the genealogy of COII genes obtained in the present and previous studies, Eurasian samples were substantially differentiated from North American samples. Since the North American population of $O$. nubilalis came from Europe, our finding suggests that there is geographical differentiation in European maize-associated $O$. nubilalis, and that maize-associated populations of $O$. nubilalis expanded multiple times in Europe. Finally, a phylogenetic analysis of the COII gene did not support that O. nubilalis and O. furnacalis are the closest relatives within the $O$. furnacalis species group.
\end{abstract}

\section{INTRODUCTION}

The European corn borer, Ostrinia nubilalis (Hübner), is one of the most serious pests of maize plants in the northern hemisphere (Showers, 1993). The native habitat of $O$. nubilalis is Europe, North Africa, and Western and Central Asia, but $O$. nubilalis was accidentally introduced into North America at the turn of the 20th century (Showers, 1993).

$O$. nubilalis is treated, in most cases, as a single extremely polyphagous species: $>200$ plant species have been recorded as larval hosts (Ponsard et al., 2004, and references therein). However, it is suspected that the nominal species $O$. nubilalis includes different populations adapted to particular host plants (Frolov, 1998). Recent studies have revealed that, at least in France, $O$. nubilalis comprises two sympatric host-associated species: a maize- and mugwort-associated species. The mugwort-associated species infests mostly mugwort and hop, while the maize-associated species infests mostly maize, and occasionally other plants such as sunflower, cocklebur, bird pepper, and sorghum (Leniaud et al., 2006). These two host-differentiated species are genetically differentiated from each other (Bourguet et al., 2000; Martel et al., 2003; Leniaud et al., 2006), and show assortative mating in the field and in cages (Malausa et al., 2005; Bethenod et al., 2005). The mechanisms resulting in reproductive isolation include differences in the female sex pheromone blend (Thomas et al., 2003; Pélozuelo et al., 2004; Bontemps et al., 2004; Leniaud et al., 2006), an unidentified factor that works at close-range in mate discrimination (Pélozuelo et al., 2007), time of year of adult emergence (Thomas et al., 2003; but see also Malausa et al., 2005) and choice of host by ovipositing females (Bethenod et al., 2005). Also, in the European part of the former Soviet Union, the mating of maize- and mugwort/hemp-associated populations of $O$. nubilalis is generally less successful than the mating success within each population (Frolov, 1998). Moreover, the host-associated populations show several ecological distinctions (Frolov, 1998; Frolov et al., 2007). Thus, the maize-associated $O$. nubilalis is likely to have species status in much of Europe. Interestingly, the Ostrinia populations associated with plants other than maize in France and the European part of the former Soviet Union are not always the same (Frolov, 1998; Frolov et al., 2007). The mugwort-associated species in France is morphologically indistinguishable from the maize-associated species of $O$. nubilalis. On the other hand, in several regions of the former Soviet Union, borers collected from hop/hemp are morphologically identified as $O$. scapulalis or O. narynensis. Frolov et al. (2007) argue that the mugwort/hop/hemp-associated $O$. nubilalis, $O$. narynensis and $O$. scapulalis in Europe, and O. orientalis in

\footnotetext{
* Present address: Agricultural Chemicals Research Laboratory, Sumitomo Chemical Company, Ltd., Takarazuka, Japan.

** Present address: National Institute of Agrobiological Sciences, Tsukuba, Japan.

*** Present address: Okinawa Prefectural Agricultural Research Center, Itoman, Japan.
} 
the Far East represent a biological species, but this argument is not yet unanimously accepted.

The maize-associated $O$. nubilalis would have colonized maize plants after the introduction of the crop into Europe ca. 500 years ago (for a review, Rebourg et al., 2003). Damage to maize by $O$. nubilalis in Europe was first recorded in Russia and France in 1879, namely $>350$ years after the introduction of maize into Europe (Keppen, 1883; Robin \& Laboulbène, 1884). The maizeassociated $O$. nubilalis may have already been present prior to the introduction of maize, utilizing plants other than maize as the larval host. Alternatively, it may have evolved from a preexisting $O$. nubilalis population after maize cultivation began in Europe. Malausa et al. (2007) suggested that the latter hypothesis is not very likely based on a population genetic analysis of the variation in four nuclear genes. In either case, it is likely that the population of maize-associated $O$. nubilalis increased rapidly in size and geographical range as maize cultivation spread in Europe. It is not clear whether this expansion started in a single or multiple geographical region(s).

When a population expands from a small size, it may develop several population genetic characteristics, particularly in animal mitochondrial DNA (mtDNA), such as little molecular diversity, deviations from the neutral equilibrium state of molecular evolution, a star-like pattern in gene genealogy, and an excess of rare sequence types (Tajima, 1989; Slatkin \& Hudson, 1991; Fu, 1997; Avise, 2000). Such patterns are evidence of a population expansion, and except for the limited molecular diversity, can be clearly detected only when a population accumulates enough mutations in mtDNA after the onset of population expansion. Therefore, the maize-associated $O$. nubilalis may show a low level of mtDNA diversity, but not clear evidence of population expansion, such as a star-like genealogy and excess of rare sequence types, since the supposed expansion of the maize-associated $O$. nubilalis population occurred $<500$ years ago, which is probably too recent for a significant accumulation of mutations in mtDNA (cf. Vilà et al., 1999).

There are few population genetic studies on mtDNA of the European populations of $O$. nubilalis. Martel et al. (2003) examined mtDNA variation within and between the maize- and mugwort-associated species in France by conducting a restriction fragment length polymorphism (RFLP) analysis. They found that one haplotype was predominant at all localities sampled. Keszthelyi \& Ács (2005) examined mtDNA variation in Hungarian and Egyptian samples of maize-associated $O$. nubilalis, by performing a single-strand conformation polymorphism analysis and did not find any mtDNA polymorphisms. This lack of diversity in mtDNA may be because the population of maize-associated $O$. nubilalis expanded from a small size, which would be supported if the limited diversity of mtDNA in the maize-associated $O$. nubilalis also applies to a wider region of Europe. It is not clear whether there is geographical differentiation in the maize-associated species of $O$. nubilalis in Europe. For the North American population of $O$. nubilalis, Coates et al. (2004) examined the cytochrome oxidase subunit I (COI) and COII genes of mtDNA in 15 individuals and found 15 haplotypes. They also examined the COI-COII region of mtDNA in 1414 individuals using PCR-RFLP, and found significant differences in the haplotype frequency between the Atlantic coast and Midwestern regions as well as between sympatric univoltine and bivoltine populations in Minnesota.

$O$. nubilalis is a member of the $O$. furnacalis species group in which Mutuura \& Munroe (1970) list ten species. The ten species are morphologically very similar to each other, and their phylogeny is uncertain. In this species group, larvae of $O$. nubilalis and $O$. furnacalis use maize as a major host plant. These two species are often compared in physiological/biochemical studies (e.g. Roelofs et al., 2002; Linn et al., 2007). However, it is unknown whether these two species are the closest relatives in this species group. Kim et al. (1999) examined single sequences of the COII gene in each of six species of the $O$. furnacalis species group. They found that $O$. nubilalis is more closely related to $O$. orientalis and $O$. scapulalis than to $O$. furnacalis, but it is necessary to examine a larger number of sequences per species to be certain.

In the present study, the mitochondrial COII gene of Russian and Turkish feral samples of $O$. nubilalis infesting maize, Slovenian feral samples for which the host plant was not specified and samples from two laboratory populations of maize-associated O. nubilalis (France and Slovenia) was sequenced. Using these COII gene sequences and those of previous studies, the geographical distribution and genealogy of COII gene haplotypes in $O$. nubilalis were examined. Phylogenetic relationships of $O$. nubilalis with other Ostrinia species were preliminarily examined using the COII gene, with particular emphasis on the relationship between $O$. nubilalis and $O$. furnacalis.

\section{MATERIAL AND METHODS}

Natural populations of maize-associated $O$. nubilalis were sampled at Krasnodar, southwestern Russia and Adana, southern Turkey. Larvae were collected from stems of maize. The larvae from Russia were reared to adulthood in the laboratory and DNA extracted from ovaries $(n=22)$. The ovaries were used because they were also used for surveying infections with $\mathrm{Wol}$ bachia, which is found in male testes and female ovaries (see below). The larvae from Turkey were preserved in ethanol until used for DNA extraction $(n=7)$. Moths of French and Slovenian laboratory populations of maize-associated $O$. nubilalis were obtained ( $n=2$ for Bordeaux, France; $n=9$ for Bjlje, Primorska region, Slovenia) and preserved in ethanol until used for DNA extraction.

Feral moths of $O$. nubilalis were caught by sweep netting or using a light trap at Adana, Turkey $(n=3)$ and four localities in Slovenia $(n=6$ at Dobrovnik, Prekmurje region; $n=11$ at Crni $\log$, Prekmurje region; $\mathrm{n}=1$ at Tosko Celo, central Slovenia; and $n=3$ at Ozeljan, Primorska region), and preserved in ethanol until used for DNA extraction. At Adana, Dobrovnik and Ozeljan, the moths were collected in a maize field. At Tosko Celo and Crni log, the moths were collected in a forest. The larval host plants of these field-collected moths were not specified. 
TABLE 1. COII sequences used in the study. $\mathrm{n}$ - number of DNA sequences. * - these sequences are shorter than the others.

\begin{tabular}{|c|c|c|c|c|}
\hline Species & Locality & $\mathrm{n}$ & Accession No. & Reference \\
\hline \multirow[t]{7}{*}{ O. nubilalis } & Russia/Turkey/Slovenia/France & 64 & AB121300-11, AB126394-445 & Present study \\
\hline & France & 1 & EU219734 & - \\
\hline & China & 1 & EU070917 & - \\
\hline & USA & 1 & AB029540 & Kim et al. (1999) \\
\hline & USA & 1 & AF321880 & - \\
\hline & USA & 1 & AF442957 & Coates et al. (2005) \\
\hline & USA & 14 & not deposited & Coates et al. (2004) \\
\hline \multirow[t]{4}{*}{ O. furnacalis } & Japan/China/Philippines & 165 & $\begin{array}{c}\mathrm{AB} 121251-72, \mathrm{AB} 127196-285 \\
\mathrm{AB} 127287-339\end{array}$ & Hoshizaki et al. (2008) \\
\hline & Japan & 1 & AB029538 & Kim et al. (1999) \\
\hline & China & 4 & EF626670-3 & - \\
\hline & Vietnam & 5 & AJ560785-9* & - \\
\hline \multirow[t]{3}{*}{ O. orientalis } & Japan & 27 & AB121273-99 & Present study \\
\hline & Japan & 1 & AB029539 & Kim et al. (1999) \\
\hline & China & 1 & EF622418 & - \\
\hline \multirow[t]{2}{*}{ O. scapulalis } & Japan & 1 & AB029541 & Kim et al. (1999) \\
\hline & China & 1 & EF622419 & - \\
\hline O. kurentzovi & China & 1 & EF622420 & - \\
\hline O. narynensis & China & 1 & EU070916 & - \\
\hline O. zaguliaevi & Japan & 1 & AB029542 & Kim et al. (1999) \\
\hline \multirow[t]{2}{*}{ O. zealis } & Japan & 1 & AB029543 & Kim et al. (1999) \\
\hline & China & 1 & EU070915 & - \\
\hline \multirow[t]{2}{*}{ O. palustralis } & Japan & 1 & AB029545 & Kim et al. (1999) \\
\hline & Japan & 1 & AB185108 & Ohno et al. (2006) \\
\hline \multirow[t]{2}{*}{ O. latipennis } & Japan & 1 & AB029544 & Kim et al. (1999), Ohno et al. (2006) \\
\hline & China & 1 & EU070914 & - \\
\hline O. ovalipennis & Japan & 2 & AB185106-7 & Ohno et al. (2006) \\
\hline
\end{tabular}

O. orientalis inhabits Eastern Asia. This species is very closely related to $O$. nubilalis (Mutuura \& Munroe, 1970; Ishikawa et al., 1999; Kim et al., 1999; Fu et al., 2004), but does not use maize as the larval host (Ishikawa et al., 1999). We used $O$. orientalis samples $(\mathrm{n}=28$, including one sample used in Kim et al., 1999) collected at seven localities in Japan (Hokkaido, Niigata, Chiba, Nagano, Kyoto, Wakayama and Tokushima). Frolov et al. (2007) revised the taxonomy of $O$. nubilalis and its relatives: $O$. orientalis, $O$. narynensis, and the mugwortassociated $O$. nubilalis are synonymized with $O$. scapulalis. However, in the present paper "O. nubilalis" and "O. orientalis" are used in the classical sense for ease of description.

Genomic DNA was extracted either from whole insects, or the legs or female ovaries of single insects, following the method of Milligan (1992) with slight modifications. Single whole bodies were ground with a mixture of $300 \mathrm{ml}$ of $2 \times$ CTAB buffer [100 mM Tris-HCl, pH 8.0; $1.4 \mathrm{M} \mathrm{NaCl} ; 20 \mathrm{mM}$ EDTA; 2\% hexadecyltrimethylammonium bromide (CTAB)], 1 $\mu 1$ of 2-mercaptoethanol, $0.75 \mu \mathrm{l}$ of RNase A $(10 \mathrm{mg} / \mathrm{ml})$ and $1.5 \mu 1$ of proteinase $\mathrm{K}(20 \mathrm{mg} / \mathrm{ml})$. When DNA was extracted from legs or ovaries, volumes of the solutions were reduced to $1 / 3$ or $1 / 6$, respectively. The homogenates were incubated at $55^{\circ} \mathrm{C}$ for two hours, and extracted sequentially with chloroform, phenol/chloroform $(1: 1)$, and chloroform. The DNA pellet obtained by isopropanol precipitation was dissolved in $200 \mu \mathrm{l}$ of TE buffer (10 mM Tris-HCl, pH 8.0; 1 mM EDTA).

An mtDNA region spanning the COII gene was amplified using the polymerase chain reaction (PCR) and Taq DNA polymerase (Sawady Technology, Tokyo, Japan). The thermal profile of the PCR was $94^{\circ} \mathrm{C}$ for 5 min, 32 cycles of $94^{\circ} \mathrm{C}$ for 36 s, $47^{\circ} \mathrm{C}$ for $1 \mathrm{~min}$, and $70^{\circ} \mathrm{C}$ for $2 \mathrm{~min}$, and finally $70^{\circ} \mathrm{C}$ for 7 min. For the amplification, a forward primer O-tLEU (Kim et al., 1999; 5'-TAGTGCAATGGATTTAAACC-3') and an external reverse primer B-tLYS (Liu \& Beckenbach, 1992; 5'GTTTAAGAGACCAGTACTTG-3') were used. The PCR products were purified from agarose gels using a Gene Clean III kit (BIO101, La Jolla, CA, USA) and directly sequenced using a Dye Terminator Sequencing FS Ready Reaction kit or BigDye Terminator Cycle Sequencing Ready Reaction kit (PE Biosystems, Foster City, CA, USA). The nucleotide sequences were determined in both directions, using four primers: O-tLEU, B-tLYS, an internal forward primer COII-L3 (5'GATATTGAAGTTACGAATATTCAG-3') and an internal reverse primer COII-R3 (5'-CATTTATAGGGGTTATATAAG AATC-3'). The sequence products were analyzed on an automated sequencer (ABI prism 377, PE Biosystems).

Nucleotide sequences of the COII gene of $O$. nubilalis and the other 10 Ostrinia species were obtained from the literature and DDBJ/GENBANK/EMBL (Table 1). Sequences were aligned using Clustal W (Thompson et al., 1994). Aligned sequences were compiled into haplotypes using MacClade 3.05 (Maddison \& Maddison, 1992). A parsimony network (Templeton et al., 1992) of COII haplotypes in O. nubilalis was constructed using TCS 1.13 (Clement et al., 2000). In the network construction, parsimonious connections with $95 \%$ confidence were statistically verified for haplotypes that differed by up to 11 mutations. We estimated the phylogenetic relationship of haplotypes within and among Ostrinia species in two ways. First, pairwise sequence divergences between haplotypes were estimated with Kimura's two-parameter model, and then the neighbour-joining 


\begin{tabular}{|c|c|c|}
\hline Haplotype & $\begin{array}{l}333333333333333333 \\
0012224444555556 \\
5620342567744552 \\
043773932478464571\end{array}$ & Reference \\
\hline A & GCATATAAAAAAGGTATG & Present study \\
\hline B & $\ldots \ldots \ldots \ldots$ A $_{\text {A }}$ & Present study \\
\hline C & ........... & $\begin{array}{l}\text { Present study } \\
\text { Kim et al. (1999) } \\
\text { EU070917 }\end{array}$ \\
\hline D & ............ & Present study \\
\hline E & т.......... & EU219734 \\
\hline $\mathrm{F}$ & ..АТА.....АА... & Coates et al. (2004) \\
\hline G & С..АТА.......... & $\begin{array}{l}\text { AF } 442957 \\
\text { AF } 321880\end{array}$ \\
\hline $\mathrm{H}$ & ...АТАC.С....... & Coates et al. (2004) \\
\hline I & ...АТА.... TAA... & Coates et al. (2004) \\
\hline $\mathrm{J}$ & C. .АТА......АА... & Coates et al. (2004) \\
\hline $\mathrm{K}$ & ..АТА..... AAG... & Coates et al. (2004) \\
\hline $\mathrm{L}$ & ..АТА...Т..... & Coates et al. (2004) \\
\hline M & ..АТА..Т..А.Т. & Coates et al. (2004) \\
\hline $\mathrm{N}$ & ..GATA.TTTGTAA.T.. & Coates et al. (2004) \\
\hline
\end{tabular}

Fig. 1. Variable sites of the mitochondrial COII gene in $O$. nubilalis. Identity with the top sequence is denoted by a dot. The nucleotide position number refers to the COII gene in Drosophila yakuba (Clary \& Wolstenholme, 1985).

tree was constructed using PHYLIP 3.67 (Felsenstein, 2004). A bootstrap test was performed with 1000 resamplings for the evaluation of branch support. Second, we used MODELTEST 3.7 (Posada \& Crandall, 1998) to determine the model of the molecular evolution. The Akaike information criterion was chosen, and the data were best represented by the HKY $+\mathrm{I}+\mathrm{G}$ model $($ freq $\mathrm{A}=0.3899$, freq $\mathrm{C}=0.1213$, freqG $=0.0922$, freqT $=0.3965 ; \mathrm{Ti} / \mathrm{tv}$ ratio $=3.0521 ;$ Proportion of invariable sites $=$ 0.7036; Gamma distribution shape parameter $=0.7008$ ). With these parameter values, we used TREEFINDER (Jobb et al., 2004) to construct a maximum likelihood (ML) phylogeny of haplotypes. A bootstrap test was performed with 100 resamplings for the evaluation of branch support.

The distribution of COII haplotypes among groups of $O$. nubilalis samples was examined by using an exact test of population differentiation (Raymond \& Rousset, 1995), which was implemented by Arlequin 3.1 (Excoffier et al., 2005), with 200,000 steps in the Markov chain. Tajima's $D$ statistic was used to test the neutrality of evolution of the COII sequence (Tajima, 1989). Fu's $F_{\mathrm{s}}$ statistic was calculated: large negative values of $F_{\mathrm{s}}$ indicate an excess of recent mutations and reject a historical stasis in population size ( $\mathrm{Fu}, 1997)$. These population genetic calculations were performed using DnaSP ver. 3.53 (Rozas \& Rozas, 1999).

Parasitic bacteria of the genus Wolbachia modify the reproduction of arthropod hosts in various ways, and consequently a Wolbachia infection may affect the mtDNA polymorphism of a host (Johnstone \& Hurst, 1996; Ballard, 2000). Wolbachia has not been found to infect $O$. nubilalis (Kageyama et al., 2004), but does infect two closely related species, $O$. furnacalis and $O$. scapulalis, causing the production of all-female progeny by male-killing (Sakamoto et al., 2007; see also Kageyama \& Traut, 2004). In the present study, to avoid confusion caused by the effects of Wolbachia on mtDNA, we confirmed using a diagnostic PCR assay that all the samples used were uninfected with Wolbachia (Kageyama et al., 2004; S. Hoshizaki, pers. observ.). As a positive control in the PCR assay, we used DNA samples of $O$. furnacalis and $O$. scapulalis that were infected with Wolbachia from our previous studies (Kageyama et al., 2002, 2003).
TABLE 2. Distribution of COII haplotypes from O. nubilalis in Russia (RUS), Turkey (TUR), Slovenia (SVN), and France (FRA). For samples whose host plants are unspecified, $m$ and $f$ indicate moths collected in maize fields and forests, respectively. SV-m includes the Dobrovnik and Ozeljan samples, and SV-f includes Tosko Celo and Crni log samples.

\begin{tabular}{ccccccccc}
\hline \multirow{2}{*}{$\begin{array}{c}\text { Haplo- } \\
\text { type }\end{array}$} & \multicolumn{4}{c}{ Host: maize } & & \multicolumn{3}{c}{ Host: unspecified } \\
\cline { 2 - 4 } \cline { 7 - 8 } & RUS & TUR & SVN & FRA & & TUR-m SVN-m & SVN-f \\
\hline A & 4 & - & - & - & & - & 1 & 1 \\
B & 1 & 2 & - & - & & - & 1 & - \\
C & 17 & 5 & 9 & 2 & & 3 & 6 & 11 \\
D & - & - & - & - & & - & 1 & - \\
\hline
\end{tabular}

\section{RESULTS}

There were only four haplotypes (haps. A-D; Fig. 1) of COII genes (682 bp) from 64 individuals of $O$. nubilalis from Russia, Turkey and Slovenia (DDBJ/GENBANK/ EMBL accession numbers AB121300-AB121311, AB126394-AB126445). These haplotypes were compared with other $O$. nubilalis COII sequences available in the literature and DDBJ/GENBANK/EMBL database (Table 1). A total of $15 \mathrm{COII}$ haplotypes were found in $O$. nubilalis (Fig. 1).

The frequency distributions of haplotypes in Russian and Turkish natural populations of $O$. nubilalis infesting maize were similar: one particular haplotype, hap. $\mathrm{C}$, was predominant (Table 2). The haplotype frequencies in these populations were not significantly different $(p=$ $0.113 \pm 0.001)$. Only hap. $\mathrm{C}$ was found in the two laboratory populations (France and Slovenia) of maizeassociated $O$. nubilalis. The absence of polymorphisms may be due to the small sample sizes and/or laboratory maintenance of populations. No significant difference in haplotype frequency was found between the two groups of moths collected in different habitats (maize field and forest) in Slovenia ( $\mathrm{p}=0.567 \pm 0.002)$.

Phylogenetic relationships among the 15 haplotypes of $O$. nubilalis COII sequences were estimated using TCS analysis (Fig. 2). In this network, the COII sequences from Eurasian samples and those from North American samples were substantially differentiated. The Eurasian and North American samples did not share haplotypes other than hap. C.

Population genetic evidence for a population expansion was looked for in O. nubilalis. The TCS network of haplotypes in O. nubilalis (Fig. 2) as a whole, or its European part, did not show a star-like pattern, which is characteristic of a population expansion event in the past. Tajima's $D$ value for the natural population of maize-associated insects (Russian and Turkish samples were pooled; $\mathrm{n}=$ $29, D=-0.288, p>0.10)$ did not indicate a significant departure from neutral molecular evolution. Values of $F_{s}$ also did not provide evidence for an excess of rare haplotypes in Russian and Turkish $O$. nubilalis infesting maize (n $\left.=29, F_{s}=-0.214, p>0.10\right)$. Thus, there was no evidence for a rapid population expansion in the maizeassociated $O$. nubilalis. 


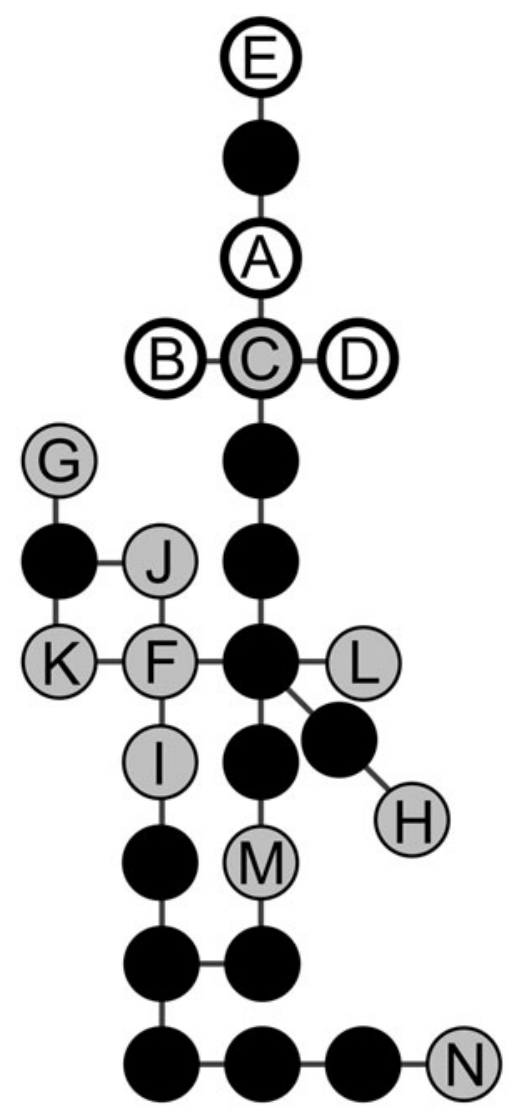

Fig. 2. A parsimonious network illustrating the phylogenetic relationships among COII gene haplotypes in $O$. nubilalis. Black circles indicate hypothetical haplotypes that were not found in the present study. Circles with a thick line indicate haplotypes found in Eurasian samples and grey circles indicate those found in samples from North America.

The COII sequences representing 11 Ostrinia species were compiled into 69 haplotypes. In this comparison, 667 nucleotides portion shared by all the sequences was used because five sequences (AJ560785-9) were shorter (667 bases) than the others (682 bases). Their phylogenetic relationships were estimated using NJ (not shown) and ML (Fig. 3) trees. In both trees, the $O$. furnacalis species group (O. furnacalis, O. nubilalis, O. orientalis, $O$. scapulalis, O. narynensis, O. kurentzovi, O. zaguliaevi, and $O$. zealis) formed a well-supported clade. The two trees showed generally similar patterns of topology and supports, and their major difference was in the position of $O$. zaguliaevi, which was positioned at the tip of a basal branch in the $O$. furnacalis group on the NJ tree, but positioned within the $O$. furnacalis clade on the ML tree. Within O. nubilalis, the North American haplotypes other than hap. $\mathrm{C}$ of $O$. nubilalis exclusively formed a wellsupported clade on both trees. The Eurasian haplotypes of O. nubilalis were scattered together with those of other species outside the North American clade. Thus, the parsimony network and ML/NJ tree showed the tendency for phylogenetic separation of Eurasian and North American samples of $O$. nubilalis. In both trees, $O$. nubilalis, $O$. orientalis, O. scapulalis, O. narynensis, and $O$. kurentzovi formed a large clade, which was not strongly supported by the bootstrap test. Two maize-pest species, $O$. furnacalis and $O$. nubilalis, did not share clades. Haps. A and $\mathrm{C}$ of $O$. nubilalis were shared by $O$. orientalis.

\section{DISCUSSION}

In terms of the mitochondrial COII gene, the Russian and Turkish populations of maize-associated $O$. nubilalis similarly showed a low level of polymorphism. This is consistent with previous findings on mtDNA of maizeassociated $O$. nubilalis in France, Hungary, and Egypt: little polymorphism was found (Martel et al., 2003; Keszthelyi \& Ács 2005). Such small variation in mtDNA may be a consequence of population bottleneck event(s) when the maize-associated $O$. nubilalis population expanded in association with the cultivation of maize in Europe. In Russian and Turkish populations of $O$. nubilalis infesting maize, there was no population genetic evidence of the population expansion, as predicted from the very recent occurrence of population expansion event(s) in the maizeassociated $O$. nubilalis (see Introduction).

The poor mtDNA diversity found in the maizeassociated $O$. nubilalis in Turkey and Russia might be explained by an alternative hypothesis. In general, diversity can become drastically reduced by strong natural selection operating on the mtDNA or other maternally inherited genetic factors (referred to as the selective sweep; Johnstone \& Hurst, 1996; Ballard, 2000). In particular, the rapid spread of a maternally-inherited factor in a host population can lead to the fixation of a single mtDNA variant, and a representative of such a genetic factor in insects is the parasitic bacterium, Wolbachia (Werren, 1997; Stouthamer et al., 1999). However, such a scenario mediated by Wolbachia infection can be disregarded since none of the $O$. nubilalis samples used in the present study were infected with Wolbachia.

A more interesting finding of the present study is the substantial divergence between North American and Eurasian COII sequences. This suggests geographical differentiation among some European populations of maizeassociated $O$. nubilalis because the North American population of $O$. nubilalis was introduced from Europe (Showers, 1993). It also tempts us to speculate that the maize-associated $O$. nubilalis population expanded in multiple localities in its natural distribution range in association with the cultivation of maize. However, the present findings give little information on the geographical pattern of differentiation among local populations of European $O$. nubilalis associated with maize, due to the geographically limited range of the samples in the present study. The mtDNA polymorphism in the maizeassociated $O$. nubilalis should be examined over a wider geographical area of its natural range.

In the maize-associated $O$. nubilalis in Europe, there are two races based on the female sex pheromone blend ( $Z$ and $E$ races). The $Z$ race occurs throughout Europe, with the two races apparently coexisting in Italy and Switzerland (Anglade et al., 1984). It would be interesting to compare the mtDNA variation between populations in southern Europe and other regions. 


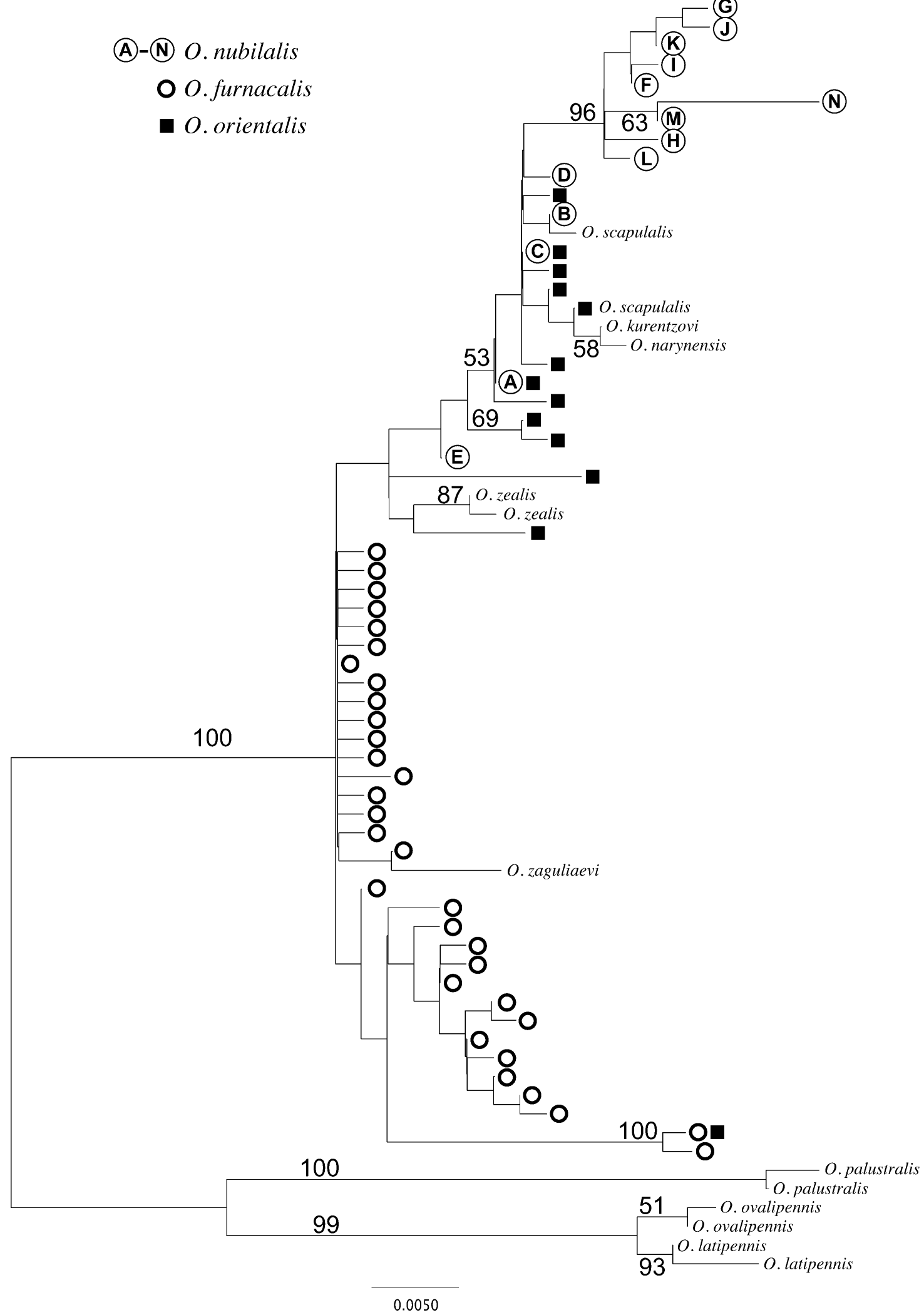

Fig. 3. A maximum likelihood tree of COII gene haplotypes in 11 species of Ostrinia. The bar indicates the genetic distance. Bootstrap support values greater than 50 (100 resamplings) are shown on branches.

In the phylogenetic tree of COII genes in 11 species of Ostrinia, O. furnacalis is monophyletic, while $O$. nubilalis formed a clade together with $O$. orientalis, O. scapulalis, O. narynensis, and O. kurentzovi. This does not support that $O$. nubilalis and $O$. furnacalis are the closest relatives in the $O$. furnacalis species group. These two species favour maize and other Poaceae plants as host for their larvae. However, if the two species are not the 
closest relatives, it does not necessarily support that the similar host-preferences between the two species share the evolutionary origin. The closer relationship among $O$. nubilalis, O. orientalis, and $O$. scapulalis is consistent with the diversity of sex pheromone components among Ostrinia species. The sex pheromone of females of $O$. nubilalis, $O$. orientalis, and $O$. scapulalis has the same major components $[(E)$ - and (Z)-11-tetradecenyl acetates], while that of $O$. furnacalis females has components [(E)- and (Z)-12-tetradecenyl acetates] unique in this genus (reviewed by Ishikawa et al., 1999). Indeed, in terms of its external morphology, O. nubilalis is indistinguishable from O. orientalis (Mutuura \& Munroe, 1970).

However, the present results do not allow us to draw a conclusion about the species phylogeny in the genus Ostrinia, including which species is closest to $O$. nubilalis. First, neither $O$. nubilalis, $O$. orientalis, O. scapulalis nor $O$. furnacalis are monophyletic in the COII tree. Second, sampling density in the present analysis was biased to $O$. nubilalis, $O$. furnacalis and $O$. orientalis. More rigorous sampling of other species is required. Finally, the statistical support was weak for most internal branches of the COII tree. To obtain a more reliable phylogenetic estimate, it would be necessary to examine not only longer mitochondrial but also nuclear sequences.

Finally, we address the importance of a phylogeographic/phylogenetic perspective in ecological studies on $O$. nubilalis. In the present paper, we suggest that there may be a geographical differentiation in European maizeassociated $O$. nubilalis. If so, it is relevant to the development of a management strategy for $O$. nubilalis in Europe. It may also be relevant to the study of speciation between the maize-associated and mugwort/hopassociated $O$. nubilalis. A better knowledge of the geographical pattern of differentiation in maize-associated $O$. nubilalis in Europe would help to extend the $O$. nubilalis speciation study done in France, which is reviewed in the Introduction.

ACKNOWLEDGEMENTS. This work was supported in part by Grants-in-Aid (Nos 12640675 and 13460021) from the Ministry of Education, Science, Sports and Culture, Japan. We thank T. Takanashi for help with rearing the insects. We also thank F. Marion-Poll for the French samples of $O$. nubilalis and for comments on the manuscript.

\section{REFERENCES}

Anglade P., Stockel J. \& I.W.G.O. Cooperators 1984: Intraspecific variability in the European corn borer, Ostrinia nubilalis Hbn. (Lepidoptera: Pyralidae). Agronomie 4: 183-187.

Avise J.C. 2000: Phylogeography: The History and Formation of Species. Harvard University Press, Massachusetts, $447 \mathrm{pp}$.

BALLARD J.W.O. 2000: Comparative genomics of mitochondrial DNA in Drosophila simulans. J. Mol. Evol. 51: 64-75.

Bethenod M.-T., Thomas Y., Rousset F., Frérot B., Pélozuelo L., Genestier G. \& Bourguet D. 2005: Genetic isolation between two sympatric host plant races of the European corn borer, Ostrinia nubilalis Hübner. II: Assortative mating and host-plant preference for oviposition. Heredity 94: 264-270.

Bontemps A., Bourguet D., Pélozuelo L., Bethenod M.-T. \& Ponsard S. 2004: Managing the evolution of Bacillus thuringiensis resistance in natural populations of the Euro- pean corn borer, Ostrinia nubilalis: host plant, host race and pherotype of adult males at aggregation sites. Proc. R. Soc. Lond. (B) 271: 2179-2185.

Bourguet D., Bethenod M.T., Trouvé C. \& Viard F. 2000: Host-plant diversity of the European corn borer Ostrinia nubilalis: what value for sustainable transgenic insecticidal $\mathrm{Bt}$ maize ? Proc. R. Soc. Lond. (B) 267: 1117-1184.

Clary D.O. \& Wolstenholme D.R. 1985: The mitochondrial DNA molecule of Drosophila yakuba: nucleotide sequence, gene organization, and genetic code. J. Mol. Evol. 22: 252-271.

Clement M., Posada D. \& Crandall K.A. 2000: TCS: a computer program to estimate gene genealogies. Mol. Ecol. 9: $1657-1659$.

Coates B., Sumerford D.V. \& Hellmich R.L. 2004: Geographic and voltinism differentiation among North American Ostrinia nubilalis (European corn borer) mitochondrial cytochrome c oxidase haplotypes. J. Insect Sci. 4: 35.

Coates B.S., Sumerford D.V., Hellmich R.L. \& Lewis L.C. 2005: Partial mitochondrial genome sequence of Ostrinia nubilalis and Ostrinia furnacalis. Int. J. Biol. Sci. 1: 13-18

Excoffier L., LAVAl G. \& SChNeider G. 2005: Arlequin ver. 3.0: an integrated software package for population genetics data analysis. Evol. Bioinform. Online 1: 47-50.

Felsenstein J. 2004: PHYLIP (Phylogeny Inference Package) version 3.6. Distributed by the author. Department of Genome Science, University of Washington, Seattle.

Frolov A.N. 1998: Variation in the European corn borer, Ostrinia nubilalis, and allies (Lepidoptera: Pyralidae). Mém. Soc. R. Belg. Entomol. 38: 1-21.

Frolov A.N., Bourguet D. \& Ponsard S. 2007: Reconsidering the taxonomy of several Ostrinia species in the light of reproductive isolation: a tale for E. Mayr. Biol. J. Linn. Soc. 91: 49-72.

FU Y.X. 1997: Statistical tests of neutrality of mutations against population growth, hitchhiking and background selection. Genetics 147: 915-925.

Fu X.Y., Tabata J., Huang Y., Takanashi T., Ohno S., Honda H., TAtsuki S. \& IshiKawa Y. 2004: Female sex pheromone of Ostrinia orientalis - throwing a light on the relationship between $\mathrm{O}$. orientalis and the European corn borer, O. nubilalis. Chemoecology 14: 175-180.

Hoshizaki S., Washimori R., Kubota, S., Ohno, S., Huang Y.P., TATsuKi S. \& IshiKawa Y. 2008: Two mitochondrial lineages occur in the Asian corn borer Ostrinia furnacalis (Lepidoptera: Crambidae) in Japan. Bull. Entomol. Res. (in press)

Ishikawa Y., Takanashi T., Kim C.-G., Hoshizaki S., Tatsuki S. \& HuANG Y. 1999: Ostrinia spp. in Japan: their host plants and sex pheromones. Entomol. Exp. Appl. 91: 237-244.

Jobb G., von Haeseler A. \& Strimmer K. 2004: TREEFINDER: a powerful graphical analysis environment for molecular phylogenetics. BMC Evol. Biol. 4: 18.

Johnstone R.A. \& HuRst G.D.D. 1996: Maternally inherited male-killing microorganisms may confound interpretation of mitochondrial DNA variability. Biol. J. Linn. Soc. 58: 453-470.

Kageyama D. \& Traut W. 2004: Opposite sex-specific effects of Wolbachia and interference with the sex determination of its host Ostrinia scapulalis. Proc. R. Soc. Lond. (B) 271: 251-258.

Kageyama D., Nishimura G., Hoshizaki S. \& IshiKawa Y. 2002: Feminizing Wolbachia in an insect, Ostrinia furnacalis (Lepidoptera: Crambidae). Heredity 88: 444-449.

Kageyama D., Nishimura G., Hoshizaki S. \& Ishikawa Y. 2003: Two kinds of sex ratio distorters in a moth, Ostrinia scapulalis. Genome 46: 974-982. 
Kageyama D., Nishimura G., Ohno S., Takanashi T., Hoshizak S. \& IsHIKAWA Y. 2004: Wolbachia infection and an allfemale trait in Ostrinia orientalis and Ostrinia zaguliaevi (Lepidoptera: Crambidae). Entomol. Exp. Appl. 111: 79-83.

Keppen F. 1883: Harmful Insects. Vol. 3. St. Petersburg [in Russian].

KesZThelyi S. \& Ács Z. 2005: Comparison on DNA patterns of different ecotypes of European corn borer (Ostrinia nubilalis Hübner) in Hungary. Acta Biol. Hungar. 56: 75-81.

Kim C.-G., Hoshizaki S., Huang Y., Tatsuki S. \& IshiKawa Y. 1999: Usefulness of mitochondrial COII gene sequences in examining phylogenetic relationships in the Asian corn borer, Ostrinia furnacalis, and allied species (Lepidoptera: Pyralidae). Appl. Entomol. Zool. 34: 405-412.

Leniaud L., Audiot P., Bourguet D., Frérot B., Genestier G., Lee S.F., Malausa T., Le Pallec A.-H., Souqual M.-C. \& PonSARD S. 2006: Genetic structure of European and Mediterranean maize borer populations on several wild and cultivated host plants. Entomol. Exp. Appl. 120: 51-62.

LinN C.E. JR., Musto C.J. \& Roelofs W.L. 2007: More rare males in Ostrinia: response of Asian corn borer moths to the sex pheromone of the European corn borer. J. Chem. Ecol. 33: $199-212$.

Liu H. \& Beckenbach A.T. 1992: Evolution of the mitochondrial cytochrome oxidase II gene among 10 orders of insects. Mol. Phylogen. Evol. 1: 41-52.

Maddison W.P. \& MadDison D.R. 1992: MacClade: Analysis of Phylogeny and Character Evolution. Version 3. Sinauer Associates, Massachusetts.

Malausa T., Bethenod M.-T., Bontemps A., Bourguet D., CorNUET J.-M. \& Ponsard S. 2005: Assortative mating in sympatric host races of the European corn borer. Science 308: $258-260$

Malausa T., Leniaud L., Martin J.-F., Audiot P., Bourguet D., Ponsard S., Lee S.-F., Harrison R.G. \& Dopman E. 2007 Molecular differentiation at nuclear loci in French host races of the European corn borer (Ostrinia nubilalis). Genetics 176: $2343-2355$

Martel C., Réjasse A., Rousset F., Bethenod M.-T. \& BourGUET D. 2003: Host-plant-associated genetic differentiation in northern French populations of the European corn borer. Heredity 90: 141-149.

Milligan B.G. 1992: Plant DNA isolation. In Hoelzel A.R. (ed.): Molecular Genetic Analysis of Populations: A Practical Approach. Oxford University Press, New York, pp. 59-88.

Mutuura A. \& Munroe E. 1970: Taxonomy and distribution of the European corn borer and allied species: genus Ostrinia (Lepidoptera: Pyralidae). Mém. Entomol. Soc. Can. 71: $1-112$.

Ohno S., Ishikawa Y., Tatsuki S. \& Hoshizaki S. 2006: Variation in mitochondrial COII gene sequences among two species of Japanese knotweed-boring moths, Ostrinia latipennis and O. ovalipennis (Lepidoptera: Crambidae). Bull. Entomol. Res. 96: 243-249.

Pélozuelo L., Malosse C., Genestier G., Guenego H. \& Frérot B. 2004: Host-plant specialization in pheromone strains of the European corn borer Ostrinia nubilalis in France. J. Chem. Ecol. 30: 335-352.

Pélozuelo L., Meusnier S., Audiot P., Bourguet D. \& Ponsard S. 2007: Assortative mating between European corn borer pheromone races: beyond assortative meeting. PLOS ONE 2 (6): e555. doi: 10.1371/journal.pone.0000555
Ponsard S., Bethenod M.-T., Bontemps A., Pélozuelo L., SouQUAL M.-C. \& Bourguet D. 2004: Carbon stable isotopes: a tool for studying the mating, oviposition, and spatial distribution of races of European corn borer, Ostrinia nubilalis, among host plants in the field. Can. J. Zool. 82: 1-9.

Posada D. \& Crandall K.A. 1998: MODELTEST: testing the model of DNA substitution. Bioinformatics 14: 817-818.

RAYMOND M. \& Rousset F. 1995: An exact test for population differentiation. Evolution 49: 1280-1283.

Rebourg C., Chastanet M., Gouesnard B., Welcker C., DurBreuil P. \& Charcosset A. 2003: Maize introduction into Europe: the history reviewed in the light of molecular data. Theor. Appl. Genet. 106: 895-903.

Robin O. \& Laboulbėne A. 1884: Sur les dégâts causés au mais et au chanvre par les chenilles du Botys nubilalis Hübner. Ann. Soc. Entomol. Fr. 6: 5-16.

Roelofs W.L., Liu W., Hao G., Jiao H., Rooney A. \& Linn C.E. JR. 2002: Evolution of moth sex pheromones via ancestral genes. Proc. Natl. Acad. Sci. USA 99: 13621-13626.

RoZAS J. \& RozAS R. 1999: DnaSP version 3: an integrated program for molecular population genetics and molecular evolution analysis. Bioinformatics 15: 174-175.

Sakamoto H., Kageyama D., Hoshizaki S. \& Ishikawa Y. 2007: Sex-specific death in the Asian corn borer moth (Ostrinia furnacalis) infected with Wolbachia occurs across larval development. Genome 50: 645-652.

SHOWERs W.B. 1993: Diversity and variation of European corn borer populations. In Kim K.-C. \& McPheron B.A. (eds): Evolution of Insect Pests: Patterns and Variation. John Wiley and Sons, New York, pp. 287-309.

SlatKIN M. \& Hudson R.R. 1991: Pairwise comparisons of mitochondrial DNA sequences in stable and exponentially growing populations. Genetics 129: 555-562.

Stouthamer R., Breeuwer J.A.J. \& Hurst G.D.D. 1999: Wolbachia pipientis: microbial manipulator of arthropod reproduction. Annu. Rev. Microbiol. 53: 71-102.

Tалтма F. 1989: Statistical method for testing the neutral mutation hypothesis by DNA polymorphism. Genetics 123: 585-595.

Templeton A.R., Crandall K.A. \& Sing C.F. 1992: A cladistic analysis of phenotypic associations with haplotypes inferred from restriction endonuclease mapping and DNA sequence data. III. Cladogram estimation. Genetics 132: 619-633.

Thomas Y., Bethenod M.-T., Pélozuelo L., Frérot B. \& BourGUET D. 2003: Genetic isolation between two sympatric hostplant races of the European corn borer, Ostrinia nubilalis Hübner. I. Sex pheromone, moth emergence timing, and parasitism. Evolution 57: 261-273.

Thompson J.D., Higgins D.G. \& Gibson T.J. 1994: CLUSTAL $\mathrm{W}$ : improving the sensitivity of progressive multiple sequence alignment through sequence weighting, positions-specific gap penalties and weight matrix choice. Nucl. Acids Res. 22: 4673-4680

Vilà C., Amorim I.R., Leonrad J.A., Posada D., Castroviejo J., Petrucci-Fonseca F., Crandall K.A., Ellegren H. \& Wayne R.K. 1999: Mitochondrial DNA phylogeography and population history of the grey wolf Canis lupus. Mol. Ecol. 8: 2089-2103.

WERREN J.H. 1997: Biology of Wolbachia. Annu. Rev. Entomol. 42: 587-609.

Received October 23, 2007; revised and accepted July 11, 2008 